\title{
Fiscal Decentralization and Special Local Autonomy: Evidence from an Emerging Market
}

\author{
Suwandi ${ }^{1}$ and Ari Warokka ${ }^{2}$ \\ ${ }^{1}$ Faculty of Economics - Cenderawasih University, Indonesia \\ ${ }^{2}$ Economic Development Dept., Faculty of Economics - North Sumatera University, Indonesia
}

\begin{abstract}
The quest of searching the endogeny variables of financial decentralization in emerging markets have become a serious topic due to the increasing wave of decentralized regions in many countries. The paper aimsto examine the effects of fiscal decentralization and specific local autonomy on economic growth, employment, poverty, and welfare in the special province Papua (Indonesia). The study exploited the main data of the decentralization fund by using a panel data of eight regencies and municipals, particularly the regional autonomy fund, direct and indirect government expenditure, and economic growth. The paper used the path analysis to explore the relationships of the observed variables. The results revealed that the decentralization fund influenced significantly on government's direct expenditure and economic growth. The special local autonomy's fund has influenced considerably on government's indirect expenditure. Its effect has increased, through economic growth as the intermediating variable, meaningfully on employment, poverty, and welfare. The results are in line with the prior studies, which explore the consequences of decentralization and specific autonomy to spur the economic growth in certain regions. It implies that the economic development strategies in Indonesia's less-developed regions should be started with a bigger autonomy transfer program to those regions and simultaneously enhanced it by special budget allocation to trigger and support the development.
\end{abstract}

Keywords: Perceived organizational support, organizational commitment, academic expatriate.

\section{Introduction}

One of the causes of Indonesia's economic development failure is the misleading policy, which has affected the widening disparities between regions and income groups. This unfavorable policy will continually threaten the development process in Indonesia and create a vulnerable situation to the shocks and crises. To manage this problem, the Indonesian government initiated a wider local autonomy, which was one of the reform agendas in the post Asia's financial crisis period. This special autonomy program was implemented in form of fiscal decentralization, which allocated an economic balance between central government and regional ones. The financial governance decentralization in Indonesia, which is legally based on Law No. 33/2004 on the balanced fiscal, is intended as the anchor law for the equitable development and one of the government's strategies to reduce the disparities among Indonesian regions.

The more extended regional governance will give the local government a larger autonomy to conceptualize, build, and implement their own development planning frameworks to suit the geographical context. It was intended to improve development performance at the

Copyright (C) 2013 Suwandi and Ari Warokka. This is an open access article distributed under the Creative Commons Attribution License unported 3.0, which permits unrestricted use, distribution, and reproduction in any medium, provided that original work is properly cited. Contact author: Ari Warokka E-mail: ari.warokka@yahoo.com 
provinces and regencies' level and can help to ensure policy design at the central level is relevant, supports local processes, and promotes up scaling of good practices (UNDP Indonesia, 2010). This is also consistent with the Second Fundamental Theorem of Welfare Economics (Mas-Colell, Whinston \& Green, 1995) stating that the government can actually choose the desired target of economic equality through transfers, taxation and subsidies, while the rest can be outsourced economy through market mechanisms.

However, since Law $32 / 2004$ on subnational governance and Law 33/2004 on fiscal decentralization were in force, it has created inconclusive effects of decentralization. The emerging of seven additional provinces, 164 new districts, and 34 expanded urban municipals, just gives more wage costs increased significantly and shifted to local government budgets and left few funds for much-needed capital spending in public facility's development (Eckardt \& Shah, 2007). In cross-countries literature, some recent empirical evidence suggests, on the contrary, a negative effect of fiscal decentralization on local welfare and development (Zhang \& Zou, 1998; Davoodi \& Zou, 1998). Meanwhile, some prior studies showthe positive ones, such as the work of Adi (2005) on the impact of financial decentralization on economic growth in the Java and Bali's regencies and municipals that reveals the said economic authority delegation enhances regional economic growth. Similarly, the study of Siregar (2009) found that decentralization has significantly reduced the poverty rate, even though the magnitude of the effect is relatively small. It has also reduced the level of inflation and increased the share of the agricultural and industrial sectors in the regional development that lead to the lower level of poverty.

Those debatable results have triggered us to test it in the context of Papua Special Province, the most eastern part of Indonesia, and examine the generalization power of decentralization theory. The Papua today's outlook is in paradoxical situation. On the one hand, we can see that Papua has entered a new century marked by the presence of modern governmental service, the use of information technology, and the economic activities. On the other hand, many of the indigenous Papuans still live in traditional cultures and isolated subsistence. The Papua province has also many universities. However, many Papuans are at the same time illiterate. The Papua's abundant resources unfortunately cannot support its people to live economically normal. More than $80 \%$ of Papuan households are still living in the poverty line, even some of them are inthe category of absolute poverty (Suebu, 2007). This study chose the Papua province as the research object is based on several reasons, $\mathrm{i}$. e., firstly, the disintegration threat as the result of long territorial-ownership dispute between Indonesia and Netherland for more than 18 years (1945-1963) has made the Papua's economic development is politically limited. Secondly, it is the deep-economic inequality between Papua, as one of the biggest financially contributors to the central government, and other regions in Indonesia. Thirdly, it is the Papuans' low human capital quality, both in terms of social economics and politics. And fourthly, it is a quite highly rate of human right violation cases in Papua. We summarize these unfavorable conditions as the decentralization and local autonomy's problems on economic growth, employment, poverty reduction, and equitable welfare.

Therefore, this paper is intended to explore the effect of fiscal decentralization and special regional autonomy on economic growth, employment, poverty reduction, and equitable welfare in Papua.

Information obtained from this paper will provide a further understanding and fill the literature gap in the context of the nexus of decentralization and local autonomy in the less-developed provinces and regencies. Furthermore, it will examine the underlying dimensions of the difference in the regions' conditions and potent that cause the 
disparities in the ability of local authorities to run the transferred autonomy. In addition, it is also investigating the Papuan government's self-sufficient competence in generating its own financial resources to support its economic development programs compared to the central government's balanced-fund, which is transferred to the provincial as well as district governments. The study will complete the missing puzzle of the decentralization and special autonomy's effect on emerging countries.

To present the empirical findings, the paper is organized as follows. The literature review and prior studies on fiscal decentralization, special local autonomy, economic growth, employment, poverty reduction and equitable welfare are briefly outlined in Section 2. In this section, the hypotheses' development is also developed. The methodology and research model is described in Section3, followed by the research results and discussion in Section 4. We provide some concluding remarks in Section 5.

\section{Literature Review}

The Inter-Related Nexus of Fiscal Decentralization and Special Regional Autonomy

As many developing countries are experiencing an increasing interest in government design, the main questions focus on whether it is advantageous to give subnational governments more authority and autonomy in revenue and expenditure decisions or whether it is better to make those decisions at the central level of government. Understanding the causes for fiscal decentralization leads to a more comprehensive understanding of the fiscal design of countries.

Many scholars and policy makers have sought to understand the consequences of fiscal decentralization. The decentralized financial authority is one of the main components in delegating the national government's power to subnational one (Rondinelli, 2001). Many developing countries used this delegated fiscal policy to avoid the governance's ineffectiveness and inefficiency, macroeconomic instability, and inequality economic growth (Bahl \& Linn, 1992).

Saragih (2003) argues that regional autonomy without fiscal decentralization will result less support to the achievement of the governance and public services' effectiveness. Therefore, autonomy requires financial decentralization policy. Fiscal decentralization policy aimed at enabling local government budgetary in improving service to the community, particularly in achieving minimum service standards (Seda, 2004; Mardiasmo \& Wihana, 1999). This is manifested in a policy called a financial balance between the central government and regions (Mardiasmo, 2004).

There are three missions of giving more local autonomy through fiscal decentralization (Barzelay, 1991), i.e., firstly, to create regional resource management' efficiency and effectiveness. Secondly, it is to improve the quality of public services and welfare. Thirdly, it is to empower local people and give more places to participate actively in the development process.

In general, it can be summarized that the fiscal decentralization policy is intended to solve the problem of lack of income (Buentjen, 1998), to overcome externalities and redistribution of national income (Fisher, 1996), as well as stabilize the macro economy (Davoodi, 2001). Thus, economic growth, employment, poverty reduction, and regional welfare are the main concerns in this paper to examine the effects of the said policy and autonomy on economic development. Each component will be discussed further in the following sections.

\section{Fiscal Decentralization and Economic Growth}

Theoretically, fiscal decentralization - the devolution of financial responsibilities and 
power from the central government to sub national governments - can enhance or detract from economic growth. Previous literature (Panizza, 1999; Triesman, 2006; Martinez-Vazquez \& Timofeev, 2009) and the predicted results in the theoretical framework reveal the positive sign of the log of GDP per capita exist in countries with higher levels of income with more decentralized governance.

However, the existing literatures on this decentralization itself are inconclusive. Prior studies have found a positive relationship between fiscal decentralization and economic growth (Oates, 1993; Yilmaz 1999; Iimi, 2005), others find evidence of the contrary (Xie, Zou \& Davoodi, 1999) while others establish no direct relationship (MartinezVazquez \& McNab, 2005; Thornton, 2007). Such a range of results highlights the lack of consensus in the literature on the relationship between financial decentralization and economic growth.

However, in this study, the authors stand on and develop the positive effects of fiscal decentralization and special local autonomy on economic growth based on the prior empirical findings, which are similar to our sample data. For example, Oates (1972) argues that economic efficiency can be enhanced across population groups with different preferences and needs through decentralization. Preferences for civic goods and services are likely to vary across geographically differentiated regions. If this is so, greater utility will result if different baskets of public goods and services are provided to different, homogeneous sub regions. Greater efficiency can be achieved through the mobility and sorting of the population in decentralized governments (Tiebout, 1956). Prior studies also provide some convinced arguments that regional governments are either more efficient at collecting information about people's tastes or better able to get local constituents to reveal such information (Tanzi, 2000). Other supporting authors argue that accountability plays a key role since decentralization may be the best way to create incentives for politicians to differentiate adequately between the needs of different groups of their citizens and therefore, optimize the provision of public goods (Sepulveda \& Martinez-Vazquez, 2010). Politicians would be willing to modify their objectives to satisfy preferences of their incumbents at a local level, since that would help them in reelections, based on those arguments, our first hypothesis is:

\section{$\mathrm{H}_{1 \mathrm{a}}$ : Fiscal decentralization affects the Papua Special Province's economic growth}

\section{$H_{1 b}$ : Special Local Autonomy affects the Papua Special Province's economic growth}

\section{Fiscal Decentralization, Regional Autonomy, and Employment}

One of the most important questions related to the relationship between fiscal decentralization and labor market is: Does fiscal policy create employment? Keynesian says 'yes', fiscal policy can effectively reduce unemployment. In a recession, expansionary fiscal policy will increase aggregate demand, causing higher output, leading to the creation of more jobs (Pettinger, 2008). Meanwhile, Classical Economics say in contrary. Fiscal policy will only create a pseudo employment. It will cause a temporary increase in real output as well. In the long run, expansionary fiscal policy just causes inflation and does not increase actual gross domestic product (GDP). Classical economists argue that to reduce unemployment it is necessary to use supply side policies, which increase the flexibility of labour markets (e. g. reducing power of trades unions).

However, several arguments have been made from the view point of economic efficiency that public sector size is likely to increase with the degree of fiscal decentralization. A first argument made by Oates (1985) is that greater decentralization may result in the loss of certain economies of scale with the 
consequent increase in administration costs. A second argument by Prud'homme (1995) is that the relative poorer quality of local bureaucrats is likely to weaken public expenditure management and result in higher supply costs of public services. From the viewpoint of political participation, economic historian John Wallis argued that decentralization can lead to a larger public sector because as individuals have more control over public decisions at thesubnational level, they may wish to empower the public sector with a wider range of functions and responsibilities (Prud'homme, 1995). In this point of view, civil employment is affected by the level of government decentralization in a country. The decentralized economic development creates demand for new types of government services, and that these government services will tend to rise at a faster pace.

Another important role for fiscal policy is the mitigation of unemployment and stabilization of the economy (Auerbach, Gale, \& Harris, 2010). Fiscal policy affects labor markets both through the design of tax systems and the structure of social benefits. Two key areas of fiscal policy affecting employment performance are the design of tax systems and the structure of public benefit schemes.Reductions in labor taxes can help stimulate labor demand. A revenueneutral shift from labor to consumption taxes could boost labor demand. For instance, reductions in employer social security contributions financed by higher consumption taxes (or higher recurrent property taxes) can raise labor demand by lowering (non-wage) labor costs.

The appropriately designed fiscal policies will become increasingly important in promoting employment and avoiding a shift toward informality as emerging economies expand their social benefit systems. However, a fairly recent study of 10 developing countries found that decentralization does increase total and subnational expenditures on public infrastructure (Estache \& Sinha, 1995). The major constraint on further expansion of regional services under decentralization appears to be a lack of balance between the revenue sources (including transfers) allowed to local governments, and the increases in service functions assigned to them (i.e. the creation of new public employment).

Since the Indonesia reform 1998, there has been a significant increase in indigenouspopulation importance in Indonesian societies, especially in the eastern part of Indonesia, which has generated slightly better employment conditions and gains in political power for these groups. Such changes have yielded favorable effects on their standard of living and political incorporation. At the same time, however, the said positive effects are not homogenous across regions and sectors of the economy. While many nativePapuans are able to obtain better jobs (in the private and public sectors) due to changes in labor market participation, many still suffer chronic unemployment and job turnover; high labor market segmentation keeps many members of the indigenous community working in informal labor markets (Suebu, 2007). Based on these facts, we hypothesize that:

\section{$\mathrm{H}_{2 \mathrm{a}}$ : Fiscal decentralization through economic growth affects employment}

\section{$H_{2 b}$ : Special local autonomy through economic growth affects employment}

\section{Fiscal Decentralization, Regional Autonomy and Poverty Reduction}

One of the most challenging goals of decentralization is poverty reduction. The work of Von Braun and Grote (2000) concludes that decentralization does indeed serve the poor, although the impact depends on the interaction of political, administrative and fiscal decentralization systems, and in addition, the sequencing and pace of the different types of decentralization seem to play an important role on the final-outcome. Therefore, financial decentralization may 
also affect a country's poverty reduction efforts in a number of ways. It can reduce poverty by improving these well-being components: private income, basic needs, and security. Similarly, the decentralization outcomes can be found in terms of quality of specific pro-poor services. For example, Khaleghian (2003) concludes that decentralization appears to improve the coverage of childhood immunization in lowincome countries but that the opposite holds for middle-income countries. At the same time, in the latter group, democratic government mitigates the unfavorable effects of decentralization, and decentralization reverses the negative effects of ethnic tension and ethnos-linguistic fractionalization.

Prior studies reveal there are several potential ways in which decentralization may affect fundamental needs of the population through the provision of services in areas (Bird \& Ebel, 2005; Foster, Fozzard, Naschold \& Conway, 2002) such as primary education, basic health and other social services. These public services affect the quality of life for all people, which is an important ingredient for poverty reduction. Local governments have a more institutionalized linkage with beneficiary communities, improved information, and the incentive to use this information. Consequently, regional governments are better placed to identify the poor, to respect native social identities, and to respond more efficiently to localized variations in conditions, tastes, standards, affordability, location requirements and so on for services or infrastructure (Galaso \& Ravallion, 2005).

Decentralization through delegated fiscal authority provides a prerequisite condition of empowerment and security for local regions, thus it creates conducive environment for economic growth and business development. In an indirect manner, good governance and accountability are obvious important precondition for assuring a pro-poor, pro-growth economic environment in which government services are delivered in an efficient and effective manner. In addition, fiscal empowerment of local governments in a way that brings government truly closer to the people may provide an even more direct benefit to the indigent, by strengthening their voice, representation and basic freedoms. Thus, decentralization can empower the poor through the creation of institutions that promote greater voice and participation of the less-fortunate (Crook, 2003). Based on those arguments, we hypothesize that:

\section{$\mathrm{H}_{3 \mathrm{a}}$ : Fiscal decentralization \&through economic growth affects poverty reduction}

\section{$\mathrm{H}_{3 \mathrm{~b}}$ : Special local autonomy through economic growth affects poverty reduction}

Fiscal Decentralization, Regional
$\underline{\text { Autonomy and Welfare }}$

For regional economists, the most important argument for decentralization is the creation of a higher level of efficiency, so that welfare gains can be achieved. A decentralised system can better respond to the local needs and therefore, reduce over or under consumption of public goods. Oates's decentralization theorem states that unless residents across a country are fully homogeneous in their preferences and needs of public services - an adjusted decentralised provision of public services will be more efficient than a centralized provision (Hong Vo, 2009).

Some further argue that fiscal decentralization will not only mean direct welfare improvements but also indirectly stimulate economic development, revenue mobilization, innovation in public service delivery, raise the accountability of elected officials and increase regional participation in governance (Bahl\&Bird, 2008). This is due to subnational governments' responsiveness to the demands of local citizens compared to the central government. The responsiveness will be stimulated by increased dependence 
on own source tax revenues in relation to alternative sources, e. g. intergovernmental transfers. The subnational government becomes more attentiveto local financial movements. This works both ways as citizens who pay taxes will be more inclined to demand that their local government be more transparent and accountable for their decisions (Mahon 2005). In summary, decentralised government can exploit these situations to increase social welfare.

According to Oates (1997), in a world of perfect information, a benevolent central planner could presumably introduce the differentiation in local outputs required to maximize social welfare. The traditional response to this point is to arguethat, in reality, there exist important imperfections in information. Morespecifically, individual regional governments are muchcloser to the people and geography of their respective jurisdictions; they possess knowledge of localized preferences and cost conditions that are hard to come by for a more distant central agency. Therefore, by transferring responsibilities to the local administrator, the national government aims to accomplish one or some of the following priorities: improve economic efficiency, cost efficiency, accountability and increased resource mobilization (Bird \& Vaillancourt 1998). Concentrating on a more economical perspective, a decentralized system is thought to be in a superior way at mobilizing revenue and reaching a greater share of the taxable operations. It is argued that a decentralized tax system and subnational governments, due to their closeness, have the potential to reach and control better the collection of taxes in ways that a central government cannot. The tax base can be broadened by numerous tax instruments, e. g. operative licenses for firms, betterment charges, property taxes, etc. The key is to identify what kinds of businesses exist within the community and to understand their assets and operations.

Freinkman and Yossifov (1998) found that fiscal decentralization is positively related to the share of education spending to the regional education spending, real industrial growth and purchasing power of population. They suggest that regions with more decentralized finances tend to have a lower economic decline. Based on those arguments, we hypothesize that:

\section{$\mathrm{H}_{4 \mathrm{a}}$ : Poverty reduction affects social welfare}

\section{$\mathrm{H}_{4 \mathrm{~b}}$ : Employment affects social welfare \\ $\mathrm{H}_{5 c}$ : Fiscal decentralization through economic growth affects social welfare}

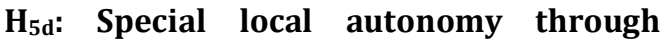 economic growth affects social welfare}

In this study, the researchers propose that fiscal decentralization and local autonomy have two types of relationship with poverty reduction, employment, and social welfare, $\mathrm{i}$. e. direct relationship and indirect relationship through economic growth as the mediating variable. Economic growth in this study is expected to improve the magnitude of the relationship between financial decentralization and regional autonomy and the endogenic variables. Baron and Kenny (1986) define the mediating variable as the mechanism through which the effect of the dependent variable can be influenced by the independent variable. The intermediary variable can increase the value of the observed variable. It measures the level of fiscal decentralization effect and special local autonomy role onpoverty reduction, employment, and social welfare. Figure 1 show the framework of this study. 


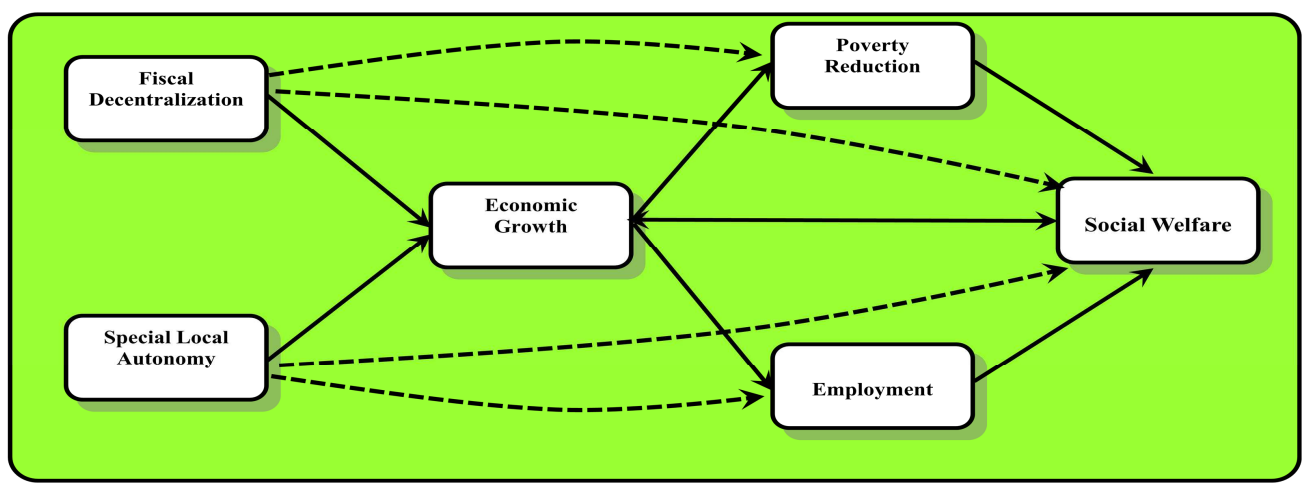
Figure 1: Research Framework on the Relationship Between Fiscal Decentralization, Special
Local Autonomy, Economic Growth, Poverty Reduction, Employment, and Social Welfare

\section{Research Methodology}

\section{Research Method and Data}

This study uses a mixed-method design for data collection and analysis. A survey was employed to collect quantitative data. Meanwhile, the research also employedindepth interviews to collect un-recorded data in Central Bureau of Statistics and interpret some of the survey findings. Survey and interviews are a good combination since a survey can collect data with breadth and interviews can collect in-depth, richer data. In this study, the researchers conducted the interviews after the survey data were collected and preliminarily analyzed.

This study was conducted at eight regencies and municipals in Special Province Papua (Indonesia), i. e. Jayapura, Biak Numfor, Nabire, Yapen, Mimika, Merauke, Keerom and Jayawijaya.These regions have implemented fiscal decentralization and particular local autonomy since 2001. The pooled data used in this study are Regional Owned-Source of Revenue (PAD), Specific Allocation Fund (DAK), General Allocation Fund (DAU), Tax- and Non Tax-Based on Revenue Sharing Funds, Gross Domestic Regional Product, Employment Index, Poverty Index, Human Development Index, and Special Autonomy Fund.The observation period is 2001-2009.

\section{Model and Data Analysis}

To test the hypotheses, this study used path analysis as shown in the following model equations:

$\mathrm{Y}_{1}=\mathrm{P}_{\mathrm{y} 1 \mathrm{x} 1} \mathrm{X}_{1}+\mathrm{P}_{\mathrm{y} 1 \mathrm{x} 2} \mathrm{X}_{2}+\varepsilon_{1}$

$\mathrm{Y}_{2}=\mathrm{P}_{\mathrm{y} 2 \mathrm{y} 1} \mathrm{Y}_{1}+\varepsilon_{2}$

$\mathrm{Y}_{3}=\mathrm{P}_{\mathrm{y} 3 \mathrm{y} 1} \mathrm{Y}_{1}+\varepsilon_{2}$

$\mathrm{Y}_{4}=\mathrm{P}_{\mathrm{y} 4 \mathrm{y} 1} \mathrm{Y}_{1}+\mathrm{P}_{\mathrm{y} 4 \mathrm{Y} 2} \mathrm{Y}_{2}+\mathrm{P}_{\mathrm{y} 4 \mathrm{y} 3} \mathrm{Y}_{3}+\varepsilon_{6}$

Where

\section{$\mathrm{X}_{1}$ : Fiscal decentralization}

$\mathrm{X}_{2}$ : Special Local Autonomy

$\mathrm{Y}_{1}$ : Economic growth

$\mathrm{Y}_{2}$ : Poverty reduction

$\mathrm{Y}_{3}$ : Employment

$\mathrm{Y}_{4}$ : Social welfare

To test model fit $\left(\mathrm{R}_{\mathrm{m}}{ }^{2}\right)$, this study used generalized $\mathrm{R}^{2}$ with equation:

$\mathrm{R}^{2}$ model $=1-\left(1-\mathrm{R}_{1}^{2}\right)\left(1-\mathrm{R}^{2}\right)\left(1-\mathrm{R}_{3}^{2}\right)(1-$ $\mathrm{R}^{2}$ ). 
9 Journal of Southeast Asian Research

\section{Results}

Table 1 shows the results of hypothesis 1,2 ,

3 , and 4.The results exhibit that all independents variable influence its observed variable significantly.

\begin{tabular}{|l|c|c|c|l|}
\hline \multicolumn{1}{|c|}{ Relation } & Beta & t-statistics & p-value & Coefficient of critical values: \\
\hline Fiscal decentralization $\rightarrow$ Economic growth & 0.239 & 2.332 & 0.024 & $\mathrm{R}^{2}=60.6 \%$ \\
\hline Special local autonomy $\rightarrow$ Economic growth & 0.341 & 3.310 & 0.002 & F-statistics $=19.572$ \\
\hline & & & & F-table $=2.553$ \\
\hline Economic growth $\rightarrow$ Employment & 0.430 & 3.497 & 0.001 & $\mathrm{R}^{2}=18.5 \%$ \\
\cline { 4 - 5 } & & & & F-statistics $=12.230$ \\
\cline { 4 - 6 } & & & F-table $=4.020$ \\
\hline Economic growth $\rightarrow$ Poverty reduction & -0.353 & -2.771 & 0.008 & $\mathrm{R}^{2}=12.5 \%$ \\
\cline { 3 - 5 } & & & & F-statistics $=7.679$ \\
\cline { 4 - 6 } & & & & F-table $=4.020$ \\
\hline Economic growth $\rightarrow$ Social welfare & 0.346 & 2.740 & 0.008 & $\mathrm{R}^{2}=47.6 \%$ \\
\hline Employment $\rightarrow$ Social welfare & 0.269 & 2.224 & 0.029 & F-statistics $=15.723$ \\
\hline Poverty reduction $\rightarrow$ Social welfare & -0.380 & -3.285 & 0.002 & F-table $=2.783$ \\
\hline
\end{tabular}

Each model informs that the overall regression (all the independent variables combined in the model) is statistically significant (there is a significant joint relationship). To test the model fit of four models developed in this study, the researchers test all combined $\mathrm{R}^{2}$, which is $\mathrm{R}_{1}{ }^{2}$ $=60.6 \%, \mathrm{R}_{2}^{2}=18.5 \%, \mathrm{R}_{3}{ }^{2}=12.5 \%$, and $\mathrm{R}_{4}{ }^{2}=$ $47.6 \%$. Thus, we get:

$\mathrm{R}^{2}{ }_{\text {model }}=1-\left[\left(1-\mathrm{R}_{1}{ }^{2}\right)\left(1-\mathrm{R}_{2}^{2}\right)\left(1-\mathrm{R}_{3}{ }^{2}\right)(1-\right.$ $\left.\mathrm{R}_{4}^{2}\right)$ ]
$\mathrm{R}^{2}$ model $=1-[(1-0.606)(1-0.185)(1-0.125)$

$(1-0.476)]$

$\mathrm{R}^{2}$ model $=1-[(0.394)(0.815)(0.875)(0.524)]$

$\mathrm{R}^{2}$ model $=0.852=85.2 \%$

The $\mathrm{R}^{2}$ model indicates all variables in the model can explain $85.2 \%$ of the causal relationship tested in the study, and $14.8 \%$ is caused by other non-tested variables. The measurement model coefficientreveals that the proposed model is fit and parsimony. 


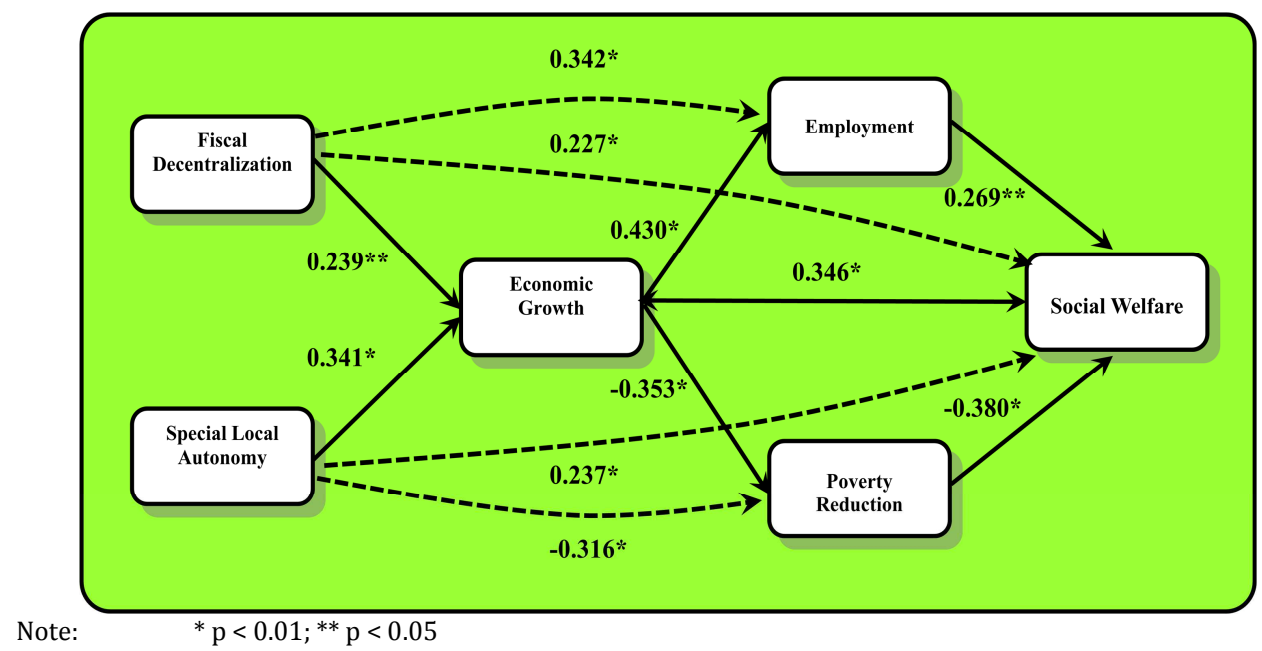

Figure 2: Path Coefficients and Hypothesis Testing of the Relationship Offiscal Decentralization, Special Local Autonomy, Economic Growth, Poverty Reduction, Employment, and Social Welfare

\section{Discussions and Implications}

The path analysis on the direct effect of fiscal decentralization on economic growth demonstrated that it had significant influence, which the path coefficient was 0.239 with $p$-value 0.024 . It means that this kind of decentralization directly influences the Papua Special Province's economic growth. This finding is in line with the work of Letelier (2005) and Martinez-Vazquez and Timofeev (2009), which find a positive relation between economic development and fiscal decentralization. It also supports the prior studies of Iimi (2005) and Stansel (2005) that finds financial decentralization fosters and enhances the economic growth as it influences particularly on the fiscal expenditure side. However, this result does not support the findings of Oates (1972), which find a negative relation between economic development and fiscal decentralization and Panizza (1999), which finds that the effect differs when outliers are excluded from theanalysis. In case of Indonesia, the researchers argue that decentralization has a direct impact on economic growth when financial decentralization is focused on public expenditure programs. The said decentralization, which is measured as government expenditure, leads to significant economic growth in the regions in which the local governments have bigger financial authority to manage and optimize its potential economic. Fiscal decentralization also increases economic efficiency, which is related to the dynamics of economic growth. Local administrator has more capabilities and advantages to manage the expenditure budget efficiently in order to satisfy the needs of regional society. It is because they know better their region.

A bigger and significant influence of fiscal decentralization on social welfare through economic growth as the mediating variable indicates that the proposed hypothesis meets the study's expectation (the path coefficient is 0.346 with p-value 0.008$)$. This kind ofdecentralization can enhance social welfare through the level and quality of economic infrastructure (roads, ports, and so on). Regional governments are critical to providing an enabling environment to ensure local economic growth, both by providing capital infrastructure as well as by promoting human capital development. In Papua, fiscal decentralization has created the welfare gains through a decentralized provision of all public goods. The same thing happens for the effect of special local autonomy on social 
welfare through economic growth. Economic growth has increased the effect positively and significantly. In the pre specificregional autonomy period, the Papua government concentrated its infrastructure development in urban areas; therefore, people who live in rural areas were not able to enjoy the effect of development. This is because, inthe pre special local autonomy period; the available development funds were relatively limited influencing the infrastructure development's priorities. As the flow of development funds to Papua fairly large, which is in the form of special autonomy funds, the local government has been able to use this fund to meet the needs of rural area's people and accelerate economic growth.

The study also foundbigger influences fiscal decentralization on employment if it was mediated by economic growth. Its effect is positive and significant. It means that fiscal decentralization and special local autonomy simultaneously have increased the number of employed people in Papua (the path coefficient is 0.430 with p-value 0.001 ). The said variables have created new investments, both in government and private sectors, which does not only trigger demand, but also increase production capacity. An enlarged production capacity requires greater other resources, i. e. human resources, to grow. It has created new employment in Papua. Decentralization has also facilitated economic growth through its impact on macro economic stability (Martinez-Vazquez \& McNab, 2005; Agenor, 2004). The said recessions decrease the probability of finding new employment and the level of earnings for those already employed.Therefore, in the case of Papua, local governments are critical to providing an enabling environment through fiscal decentralization and special regional autonomy to ensure local economic growth, both by providing capital infrastructure as well as by promoting human capital development.

Fiscal decentralization and special regional autonomy have also played important role to reduce poverty significantly through economic growth. The negative and significant coefficient of the relationship between economic growth and poverty reduction indicates that economic growth is ultimately the key to sustainable reduction of income poverty at the localized level (the path coefficient is -0.353 with p-value 0.008 ). Decentralization and localized autonomy have given more abilities to regional governance to identifyaccurately the most productive infrastructure investments in a local community. Those variables have also provided extensive local involvement in the pro-poor investment strategy. In the case of Papua, decentralization has been able to promote the inclusion of poor people in the growth process by removing constraints and empowering them to take control of their own development (through better education and health) and to take advantage of existing economically opportunities as argued in the work of Stern et al. (2005). Decentralization has potentially enhanced economic opportunities for the less-fortunate in Papua.

Some important points emerge from this discussion. First, whether decentralization has positive effects on social welfare, poverty reduction, and economic growth or not is a somewhat country- and sectorspecific issue. There are surely some types of local-impact, low capital-intensive services that are more likely to be efficiently decentralized. Meanwhile, its variations will be depended onavailable technologies, institutional structures, and local capacities, which it will influence the desirability of decentralization of a specific function in a particular country. Second, an adequate enabling environment, assignment of an appropriate set of functions to local governments, assignment ofa proper set of localized own-source revenues to regional governments, the establishment ofasuitable intergovernmental financial transfer system, and the establishment of sufficient access of local governments to development capital are the key elements that should be included in a good fiscal decentralization program. Third, by considering the current humanresource quality in Papua, fiscal 
decentralization demands a higher level of administrative skills from subnational governments, and the right competence is often a commodity short in supply in developing countries, like in Indonesia. This low competence at the regional level refers to politicians, officials and residents (Bahl \& Bird, 2008). To solve this problem local fiscal differentiation is requiredfor optimization in a multi-level public sector.

\section{Conclusion}

This study has successfully answered the research objective, which is to examine the effects of fiscal decentralization and specific local autonomy on economic growth, employment, poverty reduction, and social welfare in Papua, the most eastern part of Indonesia. From the path analysis results, it was found that fiscal decentralization and special regional autonomy had a strong indirectly influence through economic growth on employment, poverty reduction and social welfare. This finding has provided a clear path to explore more the relationship between these variables, especially in the conflicted areas in other developing countries, which is decentralization and specialized autonomy becomes the option. It is important to enhance and improve managerial and administrative effectiveness of local governance in Papua to reduce the decentralization funds' corruption rate. Hence, at the province and district level, there is a need toimprove constantly the existing human resource's entrepreneurship development. It is particularly in enhancing proper local supervision and supportive regional people involvement. The results from the study have also given some inputs to the institutional decision makers in designing more favorable policies and procedures that can help improving decentralization management in the developing regions.

\section{References}

Agenor, P. R. (2004). "Macroeconomic Adjustment and the Poor: Analytical Issues and Cross-Country Evidence," Journal of Economic Surveys, 18(3), 351.

Auerbach, A., Gale, W. \& Harris, B. (2010). "Activist Fiscal Policy," Journal of Economic Perspectives, 24(4), 141-164.

Bahl, R. \& Bird, R. (2008). "Subnational Taxes in Developing Countries: The Way Forward," Public Budgeting \& Finance, 28(4), 1-25.

Bahl, R. W. \& Linn, J. (1992). "Urban Public Finance in Developing Countries," New York: Oxford University Press.

Barzelay, M. (1991). "Managing Local Development: Lesson from Spain," Policy Sciences, 24(3), 271 - 290.

Bird, R. M. \& Ebel, R. (2005). 'Subsidiarity and Solidarity: The Role of Intergovernmental Relations in Maintaining an Effective State,' Cheltenham, UK: Edward Elgar.

Bird, R. M. \& Vaillancourt, F. (1998). Fiscal Decentralization in Developing Countries, Cambridge, UK:.Cambridge University Press.

Boadway, R. \& Shah, A. (2002). 'Poverty Alleviation under Multi-Centered Governance,' Chapter One in Fiscal Federalism: Principles and Practices, eds. Boadway and Shah. The World Bank.

Buentjen, C. (1998). 'Fiscal Decentralisation in Indonesia: The Challenge of Designing Institutions,' GTZ-SfDM Project. Jakarta.

Crook, R. C. \& Sverrisson, A. S. (2003). Does Decentralization Contribute to Poverty Reduction?, Surveying the Evidence in Peter Houtzager and Mick Moore (eds) Changing Paths: International Development and the New Politics of Inclusion, Ann Arbor: Michigan University Press.

Davoodi, H. R. (2001). 'Fiscal Decentralisation,' IMF Research Bulletin, 2(2), 5-10. 
Davoodi, H. \& Zou, H. (1998). "Fiscal Decentralization and Economic Growth: A Cross-Country Study," Journal of Urban Economics, 43, 244-257.

Estache, A. \& Sinha, S. (1995). 'Does Decentralization Increase Public Infrastructure Expenditure?,' in A. Estache, Decentralizing Infrastructure: Advantages and Limitations, Discussion Paper No. 290, World Bank, Washington, DC.

Fisher, R. C. (1996). State and Local Public Finance, Chicago: Irwin Publications.

Foster, M., Fozzard, A., Naschold, F. \& Conway, T. (2002). "How, When and Why Does Poverty Get Budget Priority: Poverty Reduction Strategy and Public Expenditure in Five African Countries," Synthesis paper.Working Paper 168, Overseas Development Institute, London.

Freinkman, L. \& Yossifov, P. (1998). "Decentralization in Regional Fiscal Systems In Russia: Trends and Links to Economic Performance," Policy Research Working Paper Series 2100, World Bank.

Galasso, E. \& Ravallion, M. (2005). "Decentralized Targeting of an Antipoverty Program," Journal of Public Economics, 89, 705-27.

Iimi, A. (2005). "Decentralization and Economic Growth Revisited: An Empirical Note," Journal of Urban Economics, 57(3), 449-61.

Khaleghian, P. (2003). "Decentralization and Public Services: The Case of Immunization," Policy Research Working Paper Series 2989, World Bank.

Letelier, L. (2005). "Explaining Fiscal Decentralization," Public Finance Review, 33(2),155.

Mahon, J. E. (2005). 'Liberal States and Fiscal Contracts: Aspects of the Political Economy of Public Finance,' Paper presented at the
Annual Meeting of the American Political Science Association.Washington, DC.

Mardiasmo (2004). 'Otonomi dan Manajemen Keuangan Daerah,' (Autonomy and regional finance management).Yogyakarta: Andi Offset Publishing.

Mardiasmo \& Kirana, W. J. (1999). 'Pengelolaan Keuangan Daerah Yang Berorientasi Pada Kepentingan Publik,' (Managing public-oriented regional finance). Yogyakarta: Kompak STIE YO Indonesia.

Martinez-Vazquez, J. \& McNab, R. (2005). "Fiscal Decentralization, Macrostability, and Growth," International Studies Program Working Paper Series at AYSPS, GSU, no. 0506, International StudiesProgram, Andrew Young School of Policy Studies, Georgia State University.

Martinez-Vazquez, J. \& Timofeev, A. (2009). "A Fiscal Perspective of State Rescaling," Cambridge Journal of Regions, Economy and Society, 2(1), 85.

Mas-Colell, A., Whinston, Michael D. \& Green, J. R. (1995). Microeconomic Theory, Oxford: Oxford University Press.

Oates, W. E. (1972). 'Fiscal Federalism,' New York: Harcourt Brace Jovanovich.

Oates, W. E. (1993). "Fiscal Decentralization and Economic Development," National Tax Journal, 46(2), 237-43.

Oates, W. E. (1997). 'On the Welfare Gains from Fiscal Decentralization,' Economiadellesceltepubbliche. 2(3), 83-92.

Panizza, U. (1999). "On the Determinants of Fiscal Centralization: Theory and Evidence," Journal of Public Economics, 74(1), 97-139.

Pettinger, T. (2008). "Does Fiscal Policy Solve Unemployment?,"Economics Help. (Accessed: October 23, 2012 at http://www.economicshelp.org/blog/226/u nemployment/does-fiscal-policy-solve-unemployment/ 
Prud'homme, R. (1995). "The Dangers of Decentralization," The World Bank Research Observer, 10(2), Washington

Rondinelli, D. A. (2001). "Making Metropolitan Areas Competitive and Sustainable in the New Economy," Journal of Urban Technology, 18(1), 1-21.

Saragih, J. P. \& Khadafi, M. S. (2003). 'Desentralisasi Fiska ldan Keuangan Daerah Dalam Otonomi,' (Fiscal decentralization and regional finance in autonomy).Jakarta: Ghalia Indonesia.

Seda, F. (2004). 'Kebijaksanaan Fiskal dan Anggaran Pendapatan dan Belanja Negara,' DalamKebijakanFiskal: Pemikiran, Konsep, dan Implementasi. Editor: Heru Subiyantoro dan Singgih Ripat. (Fiscal policy and national revenue and expenditure budget. In Heru S. \& Singgih R. Fiscal Policy: Thinking, Concept, and Implementation).Jakarta:Kompas.

Sepulveda, C. F. \& Martinez-Vazquez, J. (2010). "The Consequences of Fiscal Decentralization on Poverty and Income Inequality," International Studies Program Working Paper Series, at AYSPS, GSU.

Stern, N. H., Dethier, J. J. \& Rogers, F. H. (2005). Growth and Empowerment. Making Development Happen, Cambridge: The MIT Press.

Tanzi, V. (2000). 'On Fiscal Federalism: Issues to Worry about,' Conference on Fiscal Federalism, International Monetary Fund, Washington, D.C.

Tiebout, C. M. (1956). "A Pure Theory of Local Expenditures," The journal of political economy, 416-424.

Treisman, D. (2000). "Decentralization and Inflation: Commitment, Collective Action, Orcontinuity," American Political Science Review, 94(4), 837-857.
Vo, D. H. (2009). "The Economics of Fiscal Decentralization," Journal of Economic Surveys, 24(4), 657-679.

Von Braun, J. \& Grote, U. (2000). "Does Decentralization Serve the Poor?," Center for Development Research (ZEF Bonn). University of Bonn, Germany.

Xie, D., Zou, H.- F. \& Davoodi, H. (1999). "Fiscal Decentralization and Economic Growth in the United States," Journal of Urban Economics, 45(2), 228-39.

Yilmaz, S. (1999). 'The Impact of Fiscal Decentralization on Macroeconomic Performance,' National Tax Association, Proceedings, 251-260.

Zhang, T. \& Zou, H. (1998). "Fiscal Decentralization, Public Spending and Economic Growth in China," Journal of Public Economics, 67, 221-240. 